\title{
Demographic Profile of Donor Cornea of an Eye Bank in Tertiary Care Hospital in North India- A 9-Year Review
}

\author{
R S Chauhan ${ }^{1 *}$, Chetan Chhikara ${ }^{2}$, Ashok Rathi ${ }^{3}, \mathrm{~J} \mathrm{P} \mathrm{Chugh}^{4}$, Apoorva Goel ${ }^{5}$, Chinging Sumpi ${ }^{6}$ \\ ${ }^{1,3,4}$ Professor, ${ }^{2,5,6}$ Resident, Regional Institute of Ophthalmology Pt. B. D. Sharma, Postgraduate Institute of Medical Sciences Rohtak-124001, India
}

\begin{tabular}{l|l}
\hline DOI: $\underline{10.36348 / \text { sjmps.2020.v06i07.002 }}$ & | Received: 08.07.2020 | Accepted: $15.07 .2020 \mid$ Published: 21.07 .2020 \\
*Corresponding author: Dr. R. S. Chauhan &
\end{tabular}

Abstract

Purpose: To study the demographic profile of the donated corneas and eye donation trend of an eye bank in tertiary care hospital in North India. Study Design- Retrospective, non-comparative observational study. Material and Methods- Data from 1273 donor eyes collected from all over Haryana under Hospital Cornea Retrieval Programme (HRCP) and those collected from voluntary donors at their residence from April 2011 to March 2020 were analyzed including the demographic features like the cause of death, gender, age, and place of tissue procurement, death-enucleation time \&distance from the eye bank. Results: During the study period, 1273 corneas were retrieved from 672 donors, among which 59.2\% were males and 40.8\% were females, with donor age ranging from 12-102 years. Most of the donors were from nearby districts in Haryana and few from neighbouring state of Punjab. Maximum number of eye donations was in the age group of 51-70 years. Death enucleation time was within $6 \mathrm{hrs}$ from death in majority of the donors. 51.5\% of the donor corneas were procured from within $50 \mathrm{kms}$ from the eye bank. $60 \%$ of the corneas were collected from home and $40 \%$ under HRCP (Hospital corneal retrieval programme). The most common cause of donor death was due to old age (Natural death), followed by cardiovascular disease, trauma/multiple injury. Conclusion: Analysis of the Eye Bank registers provided valuable information in relation to eye banking and corneal utilisation in Haryana, northern India and significant trends were identified in donor demographics.

Keywords: Eye Bank, Eye Donation, Donor Cornea, Demographic profile.

Copyright @ 2020: This is an open-access article distributed under the terms of the Creative Commons Attribution license which permits unrestricted use, distribution, and reproduction in any medium for non-commercial use (NonCommercial, or CC-BY-NC) provided the original author and source are credited.

\section{INTRODUCTION}

Corneal transplantation or keratoplasty is the most commonly performed and also the most successful allogenic transplant worldwide [1]. 68,419 eyeswere donated in year 2018-19 against the set target of 50,000 [2]. A significant proportion of corneas harvested are found unsuitable for transplantation. Procurement of eyes by trained personnel, proper storage and evaluation of donated cornea is critical for the success of corneal transplantation. Around 270,000 donor corneas are required for performing 100,000 corneal transplantation surgeries in India [3].

Blindness continues to be one of the major public health problems in developing countries. Cataract and corneal diseases are major causes of blindness in countries with less-developed economies [4]. According to the World Health Organization, corneal diseases are among the major causes of vision loss and blindness in the world today, after cataract and glaucoma [5]. In India, it is estimated that there are approximately 6.8 million people who have vision less than $6 / 60$ in at least one eye due to corneal diseases; of these, about a million have bilateral involvement [6,7]. It is expected that the number of individuals with unilateral corneal blindness in India will increase to 10.6 million by 2020 [7]. According to the National Programme for Control of Blindness (NPCB) estimates, there are currently 120,000 corneal blind persons in the country. According to this estimate there is addition of 25,000-30,000 corneal blindness cases every year in the country [8].

\section{Material And Methods}

This is a retrospective observational study conducted in the Regional Institute of Ophthalmology, PGIMS, Rohtak, India. The patient records were assessed from the institutional eye bank from April 2011-March 2020. A total number of 1273 of eyes were donated during the period collected in the hospital, from voluntary donors at their residence and from other Eye Donation centres. Detailed medical history, cause of death, number of eye donations per year, age, sex, source of donation and death Enucleation time, place of 
eye donation and distance of donor's place from the eye bank. All the eyes were collected irrespective of the cause of death or any contraindication for Corneal Transplantation surgery after taking consent from family members in cases where the cornea can only be used for training or research purpose. If not willing, eyes were not procured. Serological testing was performed from the blood collected during eye donation and testing was done for HIV (Human Immunodeficiency Virus), Hepatitis B (HBsAgHepatitis B Surface Antigen), HCV (Hepatitis C Virus) $\&$ Syphilis. If the sample was found to be reactive for any of the above it was not used for corneal transplantation and discarded properly. Team involved in that particular eye donation was intimated and needful was done.

\section{RESULTS}

A retrospective analysis of 1273 donor eyes over a period of 9 years from April 2011 - March 2020. Among 672 donors, two eyes each were collected from 607 donors and one donor eye each from 65 donors. Most of the donor eyes were used for corneal transplantation and rejected donor eyes were used for training purpose or discarded if serology tested positive for HIV (Human Immunodeficiency Virus), HBsAg (Hepatitis B Surface Antigen), HCV (Hepatitis C) or Syphilis.

Out of 672 donors $(n=1273)$ there were 398 Males $(59.2 \%, \mathrm{n}=744)$ and 274 Females $(40.8 \%$, $\mathrm{n}=529)$.

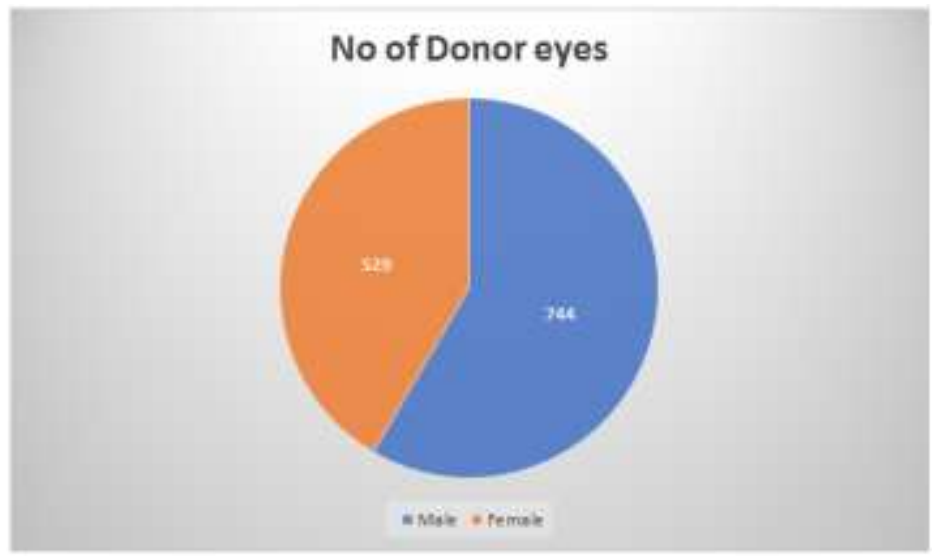

Fig-1: Gender Distribution

We divided the donors into 10 different age groups. Donor age ranged from12-102 years.

Table-1: No of donor eyes in different age groups

\begin{tabular}{|c|c|c|}
\hline AGE GROUPS & NO OF DONOR COAVEAS & PERCENTAGE \\
\hline C10 YEARS & 0 & $0.6 \%$ \\
\hline $11-20$ YEARS & 8 & $2.98 \%$ \\
\hline $21-30$ YEARS & 38 & $7.69 \%$ \\
31-40 YEARS & 98 & $14.68 \%$ \\
41-SO YEARS & 187 & $20.65 \%$ \\
$51-60$ YEARS & 263 & $27.41 \%$ \\
61-70 YEARS & 349 & $15.05 \%$ \\
71-80 YEARS & 198 & $6.99 \%$ \\
81-90 YEARS & 89 & $3.37 \%$ \\
\hline 91 YEARS \& ABOVE & 49 & \\
\hline
\end{tabular}

Detailed medical history and cause of death was noted for all the donors. Most common cause of donor death was old age (natural death $\mathrm{N}=407$ ) followed by Myocardial infarction $(\mathrm{N}=384)$ and Road traffic accident $(\mathrm{N}=79)$. 


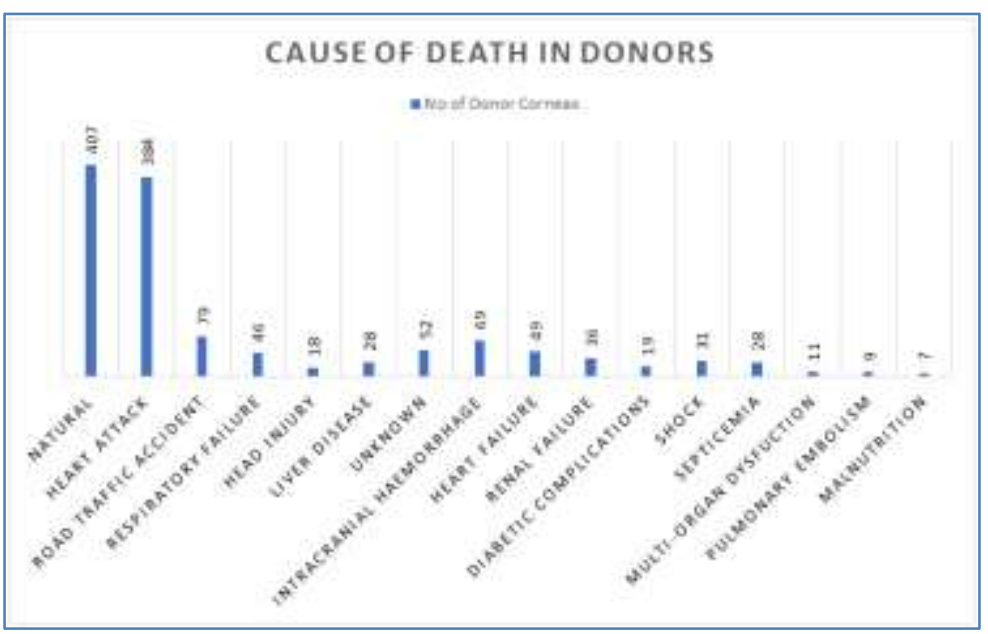

Fig-2: Cause of death in donors

Total no of eyes donated $(n=1273)$ during the study period from April, 2011 to March, 2020 were calculated yearly.

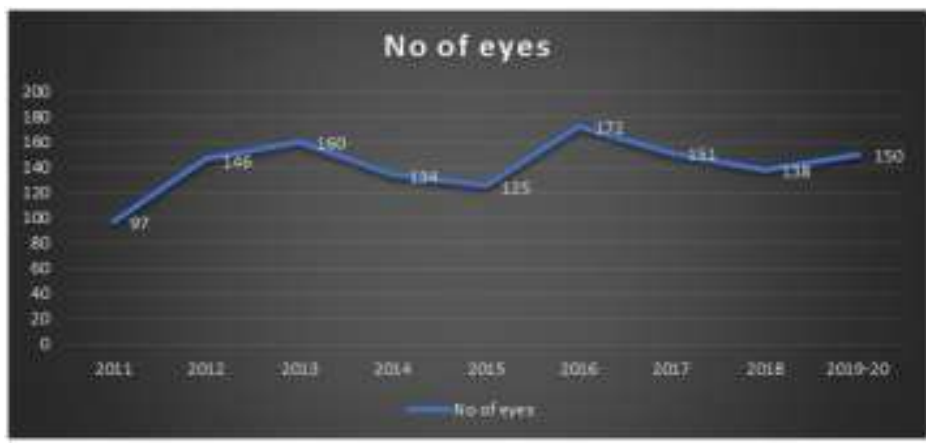

Fig-3: Trend of eye donation over the years

Majority of eye donations were from Rohtak district $28.5 \% \quad(\mathrm{n}=363)$, Bhiwani district $21.1 \% \quad(\mathrm{n}=$ 269), Jhajjar district $10.13 \%(n=129)$ followed by other district of Haryana and few from neighbouring state of Punjab.

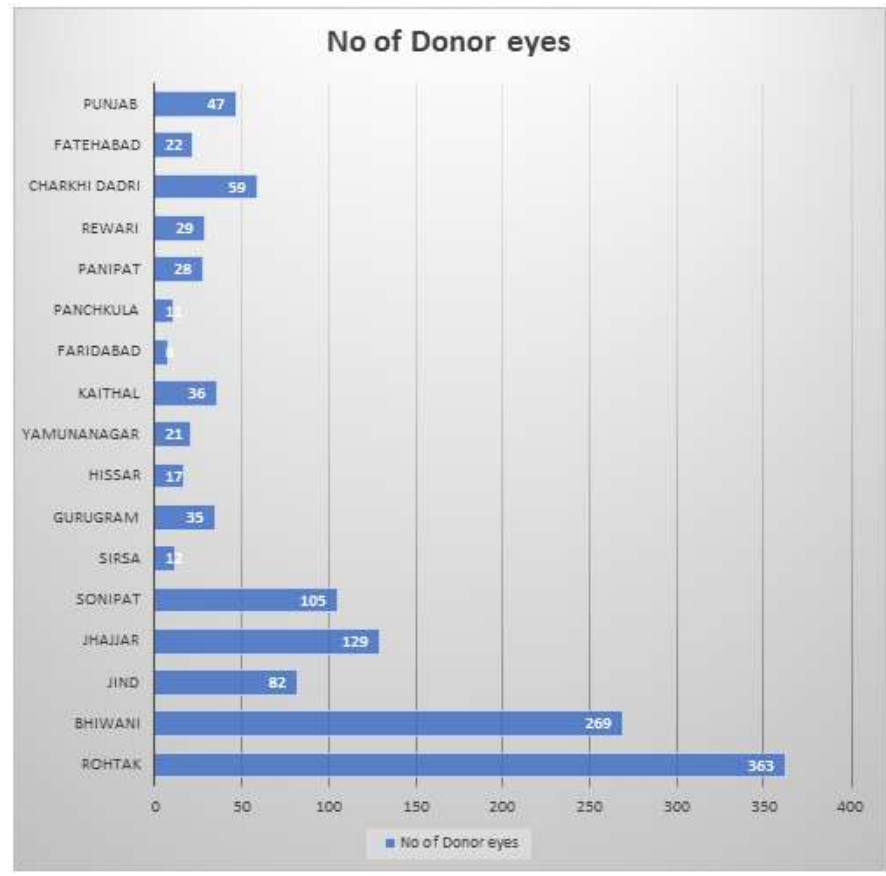

Fig-4: Place of eye donation 
Distance from place of corneal retrieval to the eye bank was noted for all the donor corneas collected during the study period and categorized into 5 groups based on the distance between the eye bank and donors place as follows Group 1- 0 to $50 \mathrm{kms}(\mathrm{n}=656,51.5 \%)$, Group 2- 51 to $100 \mathrm{kms}(\mathrm{n}=468,36.7 \%)$, Group 3- 101 to $150 \mathrm{kms}(\mathrm{n}=58,4.5 \%)$, Group $4-151$ to 200 $\operatorname{kms}(n=33,2.59 \%) \&$ Group 5- > $200 \mathrm{kms}(\mathrm{n}=58,4.5 \%)$.

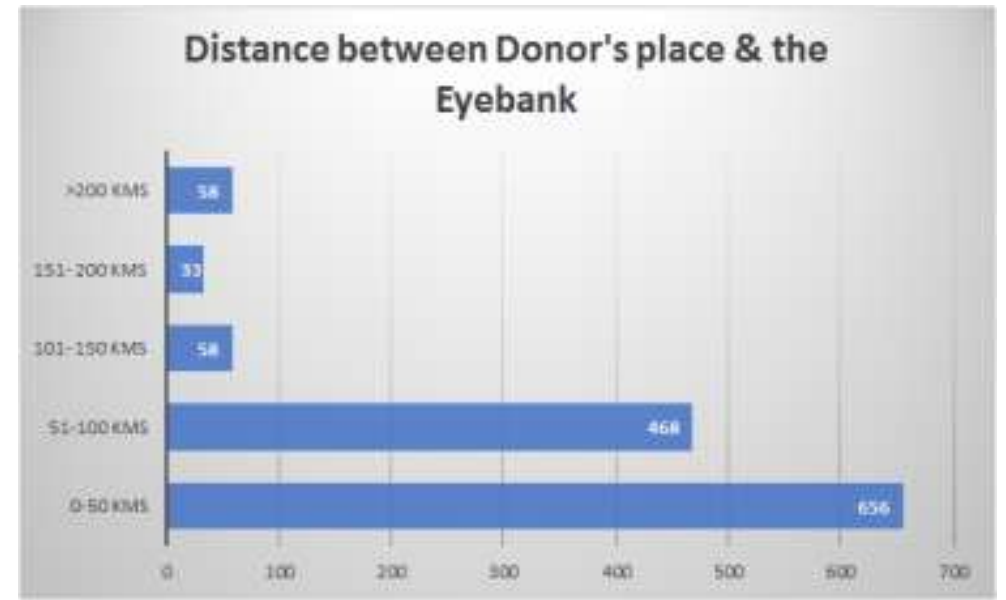

Fig-5: No of Donor eyes based on the distance between Donor's place and the Eye bank

Death Enucleation time was noted and categorized into 5 groups- Group $1=<1$ hour, Group 2=
1-2 hours, Group 3= 2-4 hours, Group 4= 4-6 hours \& Group $5=>6$ hours.

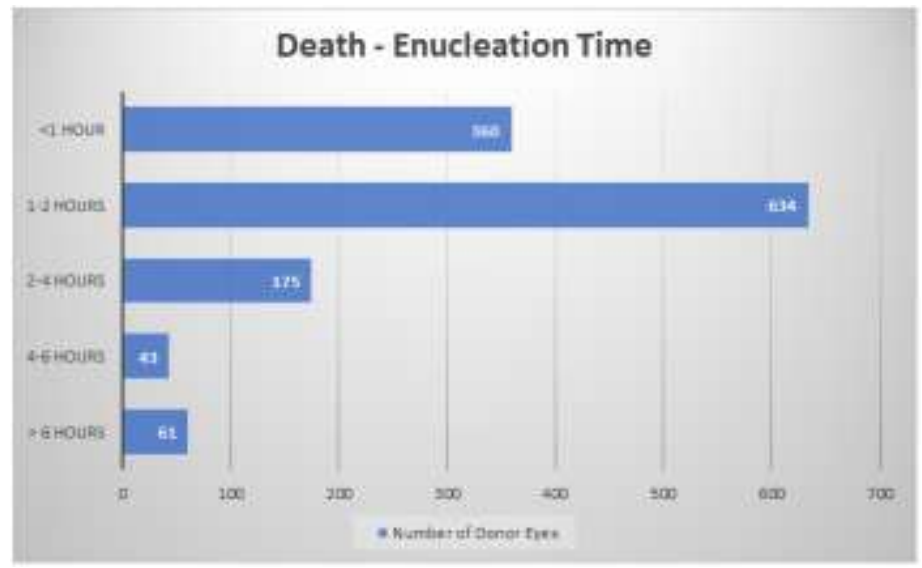

Fig-6: Death- Enucleation Time

The source of eye retrieval was analysed, $60.0 \%(n=763)$ donations were from home, followed by
$40.0 \%(\mathrm{n}=510)$ under HRCP and no eye donations from mortuary.

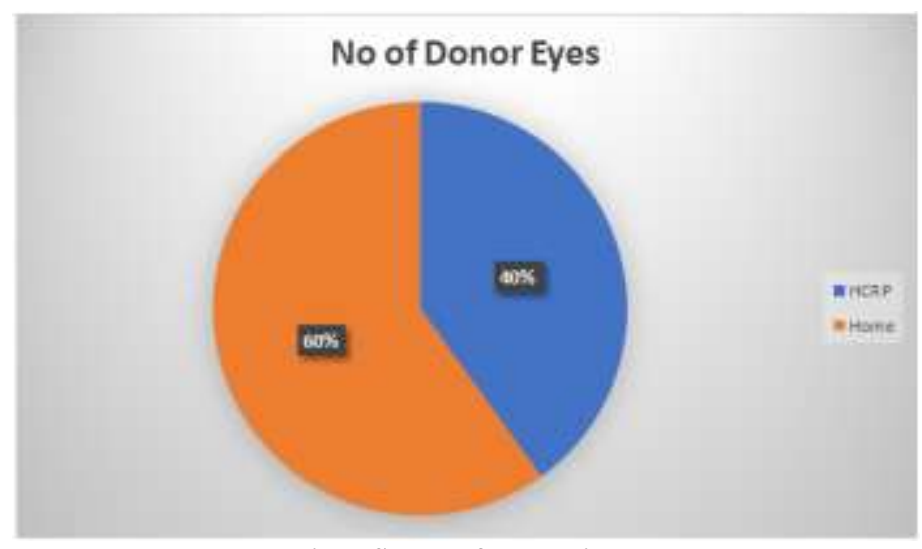

Fig-7: Source of eye retrieval 


\section{DISCUSSION}

The management of corneal blindness needs an active corneal transplantation program for restoration of vision. Corneal transplantation offers the potential for sight restoration to those who are blind from corneal diseases. Willingness to pledge their eyes for donation, relatives willing to honour that pledge upon the death of the person and procurement of transplantable donor corneas is substantial to combat the problem of corneal blindness. Efficient functioning of eye banks is crucial to meet the demand of donor corneas. Though shortage of corneas is a global phenomenon, considerable thought has perhaps not been given to the factors influencing organ donation and donor tissue procurement. Proper implementation of HCRP and proper screening of potential donors by either EB counsellors (EBC) or hospital staff can increase tissues received from hospitals and donations from deceased with no known contraindications.

Data from our study suggests that there have been increase in the number of eye donations steadily over the years but still an additional effort is required to improve awareness of eye donation in the community.

The donor age distribution from other eye banks reveals that the majority of the donors are over 60 years of age with a large population between 70 and 80 years age group [9]. We had similar results in our study, on the contrary to study by Ranjan et al. in which majority of the donors were between 41-50 years age group. The most common cause of death among donors in our study was natural death due to old age (31.9\%) followed by cardiac arrest $(30.1 \%)$ followed by road traffic accident $(6.20 \%)$. Patel et al. have shown cardiovascular diseases $(50.5 \%)$ as the major cause of death followed by trauma $(12.5 \%)$ [10].

Out of the total 1273 corneal tissue collected, $510(40 \%)$ were collected under hospital corneal retrieval programme, while $763(60 \%)$ were collected from home which is similar to Dasar et al. who have shown the majority collection from home deaths $(75.2 \%)$ followed by hospitals $(21.5 \%)$ and mortuary (3.3\%) [9]. In contrast Ranjan et al. have shown $89 \%$ collections from different hospitals, while 84 (11\%) were collected from home [11].

In our study most of the donor eyes were retrieved within six hours of death $(95.21 \%)$. The cause for delay was requirement of completion of formalities in medico legal cases before retrieval or if the place of retrieval was far away. Woodford et al.[12] showed that DPT longer than 6 hours was more likely to result in sloughing of the donor epithelium.

In our study, males were more as compared to that of females as has also been reported previously [13-16].
The age distribution of donors was comparable to published results from other eye banks, with the majority of donors being over 60 years of age and the greatest proportion between 61-70 years of age [17].

Recently, Gain et al. [18] conducted a global survey of corneal transplantation supply and demand in 148 countries. They reported that about $53 \%$ of the world's population had no access to corneal transplantation and only one cornea is available for 70 recipients in need indicating a vast shortage of corneal grafts.

A total of 2, 84, 000 corneas were reported to be procured in 82 countries with approximately $18,50,00$ corneal transplants being performed in 116 countries indicating a utilization rate of $65.1 \%$. India constituted one of the leading countries in corneal procurement along with United States and Brazil (55\% of total procurement). Also, maximum number of eye banks were identified in India (238), followed by the United States (84) and China (75) out of the total 742 eye banks. Though, the procurement of tissues and number of eyes banks are amongst the maximum in India; the utilization rate is still low. Thus, there is a great need of increasing the utility of the donor corneas by eye banks in developing countries like India. This can be achieved with continued increase in donor procurement through HCRP system.

\section{Conclusion}

Analysis of the demographic profile of the donor corneas over a period of 9 years gave useful information about the factors influencing the procurement, donor patterns, trends in eye donation over the years \& utility of donor cornea. Proper training of the medical and paramedical staff personnel for procuration of donor eyes and careful handling of the donor tissue is of vital importance to meet the shortage of corneal tissue for transplantation. Programme to increase awareness of eye donations are essential and help to decrease the prevalence of cornea blindness \& properly trained grief counsellors who can motivate the deceased family to encourage eye donation in younger age groups. Further studies are required to assess the impact of campaigns aimed at increasing awareness of eye donations and to identify existing barriers to eye donation.

\section{REFERENCES}

1. Zirm E. K. (1989). Eine erfolgreiche totale Keratoplastik (A successful total keratoplasty). 1906. Refractive \& corneal surgery, 5(4), 258-261.

2. National Programme for Control of Blindness \& Visual Impairment(NPCBVI), Directorate Generalof Health Services, Ministry of Health \& Family Welfare, Government of India. 
https://npcbvi.gov.in/writeReadData/mainlinkFile/ Physicalperformance2018-19.pdf

3. Saini J. S. (1997). Realistic targets and strategies in eye banking. Indian journal of ophthalmology, 45(3), 141-142.

4. Garg, P., Krishna, P. V., Stratis, A. K., \& Gopinathan, U. (2005). The value of corneal transplantation in reducing blindness. Eye (London, England), 19(10), 1106-1114. https://doi.org/10.1038/sj.eye.6701968

5. Causes of blindness and visual impairment. http://www.who.int/blindness/causes/en

6. National Programme for Control of Blindness Report of National Programme for Control of Blindness, India and World Health Organization. 1986-89

7. Dandona, R., \& Dandona, L. (2003). Corneal blindness in a southern Indian population: need for health promotion strategies. The British journal of ophthalmology, 87(2), 133-141.

8. National Programme for Control of Blindness. http://pbhealth.gov.in/pdf/Blindness.pdf.

9. Ranjan, A., Das, S., \& Sahu, S. K. (2014). Donor and tissue profile of a community eye bank in Eastern India. Indian journal of ophthalmology, 62(9), 935-937.

10. Patel, H. Y., Brookes, N. H., Moffatt, L., Sherwin, T., Ormonde, S., Clover, G. M., \& McGhee, C. N. (2005). The New Zealand National Eye Bank study 1991-2003: a review of the source and management of corneal tissue. Cornea, 24(5), 576582.

11. Ranjan, A., Das, S., \& Sahu, S. K. (2014). Donor and tissue profile of a community eye bank in Eastern India. Indian journal of ophthalmology, 62(9), 935-937.
12. Van Meter, W. S., Katz, D. G., White, H., \& Gayheart, R. (2005). Effect of death-topreservation time on donor corneal epithelium. Transactions of the American Ophthalmological Society, 103, 209-224.

13. Pantaleão, G. R., Zapparolli, M., Guedes, G. B., Dimartini Junior, W. M., Vidal, C. C., Wasilewski, D., \& Moreira, H. (2009). Avaliação da qualidade das córneas doadoras em relação à idade do doador e causa do óbito [Evaluation of the quality of donor corneas in relation to the age of donor and cause of death]. Arquivos brasileiros de oftalmologia, 72(5), 631-635.

14. Adán, C. B., Diniz, A. R., Perlatto, D., Hirai, F. E., \& Sato, E. H. (2008). Dez anos de doação de córneas no Banco de Olhos do Hospital São Paulo: perfil dos doadores de 1996 a 2005 [Ten years of corneal donation to the Hospital São Paulo Eye Bank: characteristics of cornea donors from 1996 to 2005]. Arquivos brasileiros de oftalmologia, 71(2), 176-181.

15. Meyer, H. J., \& Labjuhn, S. (1999). Keratoplastik und Spenderalter [Keratoplasty and donor age distribution]. Klinische Monatsblatter fur Augenheilkunde, 214(6), 367-371.

16. Raychaudhuri, A., Raychaudhuri, M., \& Banerjee, A. R. (2004). Availability of donor corneal tissue for transplantation. Tropical doctor, 34(2), 99-101.

17. Moyes, A. L., Holland, E. J., Palmon, F. E., Dvorak, J. A., \& Doughman, D. J. (1995). Tissue utilization at the Minnesota Lions' Eye Bank. Cornea, 14(6), 571-577.

18. Gain, P., Jullienne, R., He, Z., Aldossary, M., Acquart, S., Cognasse, F., \& Thuret, G. (2016). Global survey of corneal transplantation and eye banking. JAMA ophthalmology, 134(2), 167-173. 